\title{
THERAPY IN THE EARLY STAGES FOR A HEAD-INJURED PATIENT ${ }^{\dagger}$
}

\author{
H. P. MAREE, B.Sc. (Physio.) (Rand), C.T.P. (Cape Town)*
}

\begin{abstract}
Waarneming en evaluering vorm die belangrikste deel van behandeling in die vroeë stadium na hoofbeserings. Pre-operatief behoort die pasiënt so gemaklik moontlik gemaak te word en by die hantering van so 'n pasient moet die bewuswording van die totale liggaamsbeeld in ag geneem en beklemtoon word. Post-operatief of post-traumaties behoort alle aspekte van die pasient se toestand, $n l$. die sosiale, sielkundige, fisiese en emosionele probleme, aandag te geniet. Die verskillende stadia van bewustheid word bespreek en daar word veral klem gele op die feit dat personeel op normale toon met die pasient moet praat.

Evaluering moet sistematies geskied en voortdurende, noukeurige warneming is noodsaaklik. Posisionering, passiewe bewegings en die beperking van hiperaktiwiteit moet volgens die pasient se toestand benaal en toegepas word om optimum voordele vir die pasiënt in te hou. Verwaarlosing mag plaasvind as daar geen sigbare verbetering teenwoordig is nie en dit lyk asof die pasiënt nie saamwerk nic. Nogtans moet vroeë be. handeling daarop gemik wees om die pasiënt voor te berei vir latere behandeling. Doeltreffende, voldoende en effektiewe behandeling is dus die hoofdoel.
\end{abstract}

This paper was intended as a means of provoking participation by the course members by inviting them to take part in discussion and air their points of view, which they did to some extent. However, only the basic ideas are included in this article.

In any discussion of Physiotherapy in the early stages of head injury, the word "early" must first be defined. Does it include the acute and sub-acute stages of recovery, and/or the entire stage of "coming up", or only part of this?

Should the length of time since the damage occurred be measured, or the length of time since the damage was surgically repaired? Or should our yardstick be the level of consciousness reached or the degree of the patient's total response to all stimuli?

The period of time meant by this term would seem to be quite varied, totally individual and only measurable in retrospect.

The period designated "early" by the Neurosurgical Department at Groote Schuur Hospital includes "all features of primary admission for that patient" which includes complications occurring during that period.

We all know that any first treatment is a period of assessment, and a patient admitted for surgery will have pre- as well as post-operative assessment and treatment.

\section{Pre-operative Considerations}

As a general rule, when a patient is admitted for neuro-surgery, in the few days prior to surgery the patient is made as comfortable as possible. If necessary he is catheterized and sedated in order to minimize his distress.

* Lecturer, University of Cape Town.

$\uparrow$ Adapted from a paper delivered at a postgraduate course on "Early Treatment of the Head Injured Patient" held at the University of Cape Town, July 1976.
During this period the physiotherapist has an oppor. tunity to establish stimuli to which she will expect the patient to respond after surgery. In establishing a response at this stage, she is aiming at eliciting an automatic response to that same stimulus when the patient is less consciously responsive. For example the patient will become accustomed to commands and handling and will come to know how he is expected to respond in that situation.

In introducing the patient to positions which we find most useful for treatment purposes we may, at the same time, stimulate his conscious awareness of body image in favourable patterns. As far as possibl we should position and move both sides of his bod in order to stimulate total body awareness, and in so doing give the patient something definite to do and think about, thus inculcating interest in, and responsibility for, his own improvement. In any position in which he is being left for a period of time he should be encouraged to be aware of the correctness of the position and to reposition himself as far as he is able to do so.

\section{The Post-operative Period}

Post-operatively, or for emergency or traumatic admittance, the therapist's first duty is to notice, and to be constantly aware of, change or lack of change in all situations relevant to all aspects of the patient's wellbeing; including social, mental, physical and emotional aspects.

However, we must adapt our treatment to the situation as a whole because associated injuries or other conditions may take precedence.

For preliminary information we refer to the ward charts and check, among other things, drug intake, temperature, pulse rate, drips and drains, neurological responses; we note the trend of the patient's condition and establish why this should be so, as this will afied the patient's response to physiotherapy.

Should the patient be worried about his privat affairs, he could not be expected to respond readily of concentrate on his treatment and arrangements should be made to help him.

\section{Levels of Consciousness}

As a guide to the patient's progress and his ability to fespond to stimuli, we must consider his level of consciousness. Two useful ways of charting this are shown below:

(a) the academic, (ordinary type) which is precisely worded, and which aids one's general understanding of the total picture; and

(b) the clinical way, (italics) which is the most useful for practical purposes.

The clinical method assesses the patient's response to a painful stimulus, but we have no way of knowing what other stimuli are being received, registered and associated with the painful stimulus.

We cannot tell the level of acceptance of stimuli or necessarily the quality of the response, thus we must remember that there are many forms of afferent stimuli and be aware of our attitudes towards the patient. 
ALTERED STATES OF ALERTNESS OR CONSCIOUSNESS

after W. Bryan Jennet, M.D., F.R.C.S. and J. McGuire, M.C.S.P.

\begin{tabular}{|c|c|c|c|}
\hline & $\begin{array}{c}\text { Terms often } \\
\text { used }\end{array}$ & Motor Response & Verbal Response \\
\hline \multirow{6}{*}{ 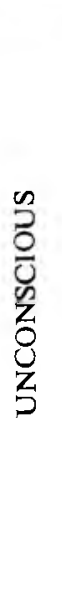 } & \multirow{4}{*}{ COMA } & $\begin{array}{l}\text { None } \\
\text { No response to stimulus } \\
\text { Flaccid } \\
\text { Outlook is grave }\end{array}$ & None \\
\hline & & $\begin{array}{l}\text { Decerebrate } \\
\text { On stimulus accentuates this posture. } \\
\text { Outlook serious. }\end{array}$ & None \\
\hline & & $\begin{array}{l}{ }^{*} 1 . \text { Withdrawal from pain } \\
\text { Decorticate. Non-purposeful } \\
\text { movement in response to stimulus. }\end{array}$ & None \\
\hline & & $\begin{array}{l}\text { *2. Localises pain } \\
\text { As above, more definite response. }\end{array}$ & Grunts only \\
\hline & STUPOR & $\begin{array}{l}\text { Obeys simple commands } \\
\text { On stimulus - purposeful response } \\
\text { to pain }\end{array}$ & \\
\hline & & Co-ordinated spontaneous movement & Inconsequential talk \\
\hline \multirow{3}{*}{ 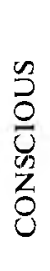 } & Confused & Normal Motor Activity & Confused but relevant replies \\
\hline & $\begin{array}{l}\text { Automatic } \\
\text { in "P.T.A." }\end{array}$ & Normal Motor Activity & $\begin{array}{l}\text { Mild disorientation only on } \\
\text { testing. } \\
\text { Disorientated but can tell } \\
\text { name, address, etc. }\end{array}$ \\
\hline & Drowsy & $\begin{array}{l}\text { Normal Motor Activity } \\
\text { Easily roused }\end{array}$ & $\begin{array}{l}\text { Orientated but sleepy } \\
\text { Can give a good account of } \\
\text { name, place, time, etc. }\end{array}$ \\
\hline
\end{tabular}

"P.T.A." = Post Traumatic Amnesia

*1. "Withdrawal" means that he indicates his displeasure by accentuating his position.

*2. "Localises" means that he tends to know where the painful stimulus is being applied.

We must talk normally, definitely, clearly and simply. I believe that tone of voice is a most important factor, particularly if the patient is slow to understand our jords. We do have a tendency to shout when we feel hat our message is not getting across, but it is important not to do this as we risk injuring the patient's self-esteem. He may well resent being spoken to as if he is an imbecile. One patient asked why she was being scolded when those talking to her had simply assumed that she was not sufficiently conscious to understand what she was being asked to do, and had therefore been talking rather loudly.

\section{Assessment}

We know, from the injuries received and the area of damage, that we may expect certain manifestations; nevertheless, assessment requires acute and continuous observation.

We are constantly trying to find better ways of assessing our patients and of recording the observations but, whether we use a chart or another method, the essential factor is that we should be systematic.

Amongst the factors for consideration are:

(i) the state of the chest;

(ii) associated injuries or diseases (also unassociated diseases) and any remedial measures pertaining to these; (iii) the position assumed by the patient, which may prove to be habitual;

(iv) the level of consciousness;

(v) the response of any part of the body to passive movement, including

(vi) changes in postural tone.

As time goes on we must:

(i) make observations on the patient's mental and emotional status and estimate his degree of attention, understanding and insight;

(ii) be alert to perceptual problems affecting his awareness of body image and quality of balance;

(iii) test for sensory disturbances, including visual and auditory abilities;

(iv) become aware of speech, communication and swallowing problems.

The question is: Where does the physiotherapist's responsibility end? How much of this may be passed over to the psychiatrists, speech, and occupational therapists? It would seem that if the physiotherapist does not receive satisfactory answers to her specific problem, she has to resort to doing appropriate tests herself.

The next three concepts are part of a whole, and are only separated for purposes of convenience. 


\section{Positioning}

Of course, the chest condition and associated injuries will dictate, to a large extent, what we are able to do but we must remember that noise from an unconscious patient is a call for help. Noise indicates that the patient's airway is partially blocked due to the fact that he is no longer in a suitable position. Deterioration of his position is less likely to happen if pillows are placed under the mattress, where possible, rather than under the patient.

Other purposes of positioning are:

(i) to prevent increased muscle tone in undesired patterns;

(ii) to keep the appropriate muscle groups under the influence of sustained stretch;

(iii) allow the patient to experience normal patterns;

(iv) to prevent the formation of bed sores.

Thus, positioning is an adjunct to passive movements or may, in itself, act as a passive movement. Maintaining the positioning pattern is not easy and in the time period between turning, the patient's position may deteriorate, therefore periodic repositioning may be required. This is most important because, as well as experiencing more normal patterns, the patient must be prevented from experiencing undesirable patterns since deformities may occur if abnormal patterns become habitual. For example, the flexion, adduction, internal rotation pattern of the hemiplegic arm becomes intensified if the scapula is strongly retracted, therefore we should aim at positioning the patient in such a way that the scapula is protracted and the arm supported in some degree of abduction.

The longer a habit has been established the more difficult it is to break and replace with an acceptable habit.

Care must be taken to prevent stimulating the released primitive reflexes, unless there is a specific reason for doing so.

\section{Passive Movements}

We know that passive movements are aimed at:

(i) increasing the circulatory rate and thereby facilitating coughing and keeping the chest clear, and preventing circulatory complications and oedema;

(ii) preventing loss of range in joints and muscles;

(iii) helping the patient to experience more normal movement patterns.

As we know, there is a strong tendency for mobility to be lost in the trunk, hip and shoulder, tendo achilles, and metacarpo-phalangeal joints of the hand. When mobilising, the rotatory element is of prime importance, as are rhythm and repetition, as these are most effective elements in helping to reduce spasticity. Full patterned movements are most useful, with specific attention being given to one joint when necessary.

There is danger in thinking that reflex inhibiting patterns can be substituted for mobilising passive movements and other movements. We must remember that a normal body requires "warming up" before further movement takes place, in order to mobilise joints and muscles and facilitate movement. Many of Professor Rood's techniques may be used successfully here: e.g. in order to stimulate the patient's response by means of the normal postural reflex mechanism, Professor Rood may swing a patient fore to aft, while he is in a prone position.

\section{Restraint}

How does one prevent the patient pulling out drip and tubes or injuring himself? Tying the patiens limbs offers an afferent stimulus. How desirable is that stimulus, or the response to that stimulus, - is to mention the patient's increasing frustration? There are occasions when patients are "coming up" or seda tion is not a suitable procedure, and in these cases the method of restraint needs to be carefully chosen, Splints and other aids should only be used if they have a positive and desirable effect. Of course accent. able aids do exist, for example boxing gloves, cot sides and fishnets. Confining the hand in a glove prevents the patient grasping the drain, but does not resist the movement entirely. Presumably the patient will not feel that his effort to remove an irritation is being deliberately thwarted. Cot sides and fishnets simply ensure that the patient will not fall out of bed while he attempts to kneel or stand. One does not wish to restrain his activities, one is concerned about his safety.

\section{Period of Neglect.}

This indicates the period during which visible im. provement is lacking - but for the physiotherapist it can be a positive and exciting period. This period does not occur during the first short while of recovery, and when it does occur the patient may be at any level of consciousness.

This causes me to think about the neuro-development of normal infants. They all follow a general pattern, but within that framework they exhibit specific personal variations. An infant may show spurts of development in one field while exhibiting slowing down or pause in another. He may develop more slowly or more quickly in a particular field. Why is this so? What is going on? I feel that we can apply the same questions to our recovering patient during the period of pause. Is he consolidating his previous improvement? Is he harness. ing his energy for the next spurt of improvement? Is he re-establishing his personality?

Of course, in the brain-damaged adult, such periods may last for a considerable length of time, during which period iced water baths may be resorted to in order to try and bring about a change in the situation.

Remembering that during illness there is a regressict in behaviour, we must ask: What shall we do? We mu not neglect the apathetic patient, nor fight the rebellious one, because future improvement depends on present treatment. Thus we may have to use a new approach and distract and inveigle the patient to respond.

\section{Conclusion}

No outcome is certain, though we do have some idea of what to expect and the individual's premorbid personality is of great importance. Early treatment prepares the patient for the later stages of treatment, thus it is important that it is adequate, effective and satisfactory. A "balanced" person is our aim, and we shall only achieve this if we give him a balanced treatment.

\section{Reference}

Jennet, W. Bryan. An introduction to Neurosurgery, 3rd Ed., William Heinemann Medical Books, London, 1973. 